\title{
Psalm 101: Inaugural address or social code of conduct?*
}

\author{
Phil J Botha \\ Department of Ancient Languages \\ University of Pretoria
}

\begin{abstract}
The article presents a literary and social-scientific analysis of the text of Psalm 101. The ideological purpose of the text seems to have been more than a mere declaration of intent made by someone about to ascend the throne. It also seems to have provided a code of conduct for an in-group of Yahweh worshippers, perhaps particularly so at a later stage of its usage. It uses royal and divine authority to demarcate the boundaries of that group and to establish a religious and social ethos for its members. Moral wholeness and social and religious integrity seem to have been the ideal characteristics of a member of this group of people whose existence is vindicated through this psalm.
\end{abstract}

\section{INTRODUCTION}

It is widely believed that Psalm 101 is a royal proclamation issued at the enthronement festival of a prince of Judah in Jerusalem. ${ }^{1}$ The psalm does indeed give the impression that its first person speaker is a member of the aristocracy. ${ }^{2}$ The speaker has a large house or palace $(v 2)^{3}$ where he accommodates other people and servants ( $v v 6$ and 7 ). He is pictured as someone with great power and judicial authority over the whole land ( $v v 5,6$, 7 , and 8$).{ }^{4} \mathrm{He}$ is also someone who should be "served" with respect (note the use of $t r v$ in verse 6$){ }^{5}$

This article is about the possible communicative functions of Psalm 101. Even in an original inaugural setting, where the words may have been spoken by a regent, a prince or a newly crowned king, ${ }^{6}$ the ideological purpose of the text seems to have been more than simply a declaration of

\footnotetext{
* With this article on a carefully constructed text that served and still serves to promote social and religious integrity, I propose to honour professor Andries Breytenbach. The ideals of this psalm are also his and I would like to thank him for his scholarly contribution to the study of the Old Testament in South Africa and his influence on my person. I have great appreciation for his social, religious, and academic integrity and great respect for his proficiency in the fields of Semitic Languages and the study of the Old Testament.
} 
intent or a prayer made by someone who was about to ascend the throne. It seems also to provide a code of conduct for a ruler and his subjects. ${ }^{7}$ It uses royal and divine authority to prescribe a way of life for the subjects of that king. It establishes a religious and social ethos and issues a warning to those members of society who deviate from this code of conduct.

The research questions for this article therefore are these: What was the communicative function of this psalm, whether it was used in a Judaic royal ritual or (later) simply in religious worship? What is the ideology of the document? How is its purpose pursued and attained in terms of textual strategy? The method that will be used to investigate these questions is that of social-scientific criticism. ${ }^{8}$ The psalm provides an opportunity to view a section of Israelite or Judaic society frozen in time. It also displays a communicative strategy. The techniques developed by social scientific criticism will be used to analyse these features. The first phase of such an analysis must be to investigate its stichometric and poetic characteristics, since these form part of the set of codes in which its textual strategy is encased.

\section{STICHOMETRIC ANALYSIS}

\begin{tabular}{|c|c|c|c|c|c|}
\hline & & & 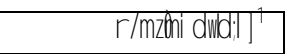 & $1 a$ & Of David. A Psalm. \\
\hline \multirow[t]{6}{*}{ I } & A & 1 & hr jtat; Pv mlladsj, & $\mathrm{b}$ & Of loyalty and justice I will sing; \\
\hline & & & . hr Mezą \}h wh yoo I] & C & to you, Yahweh, I will sing a psalm. \\
\hline & & 2 & 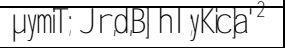 & $2 a$ & I will give heed to ${ }^{9}$ a blameless way. \\
\hline & & & $y / \rightarrow$ ea $/ b T ; y^{t} m_{i}$ & $\mathrm{~b}$ & When will you come to me? ${ }^{10}$ \\
\hline & & 3 & $\mathrm{yb} b / A \mu t \mathrm{~B}] \int\left[\mathrm{\theta t}_{\mathrm{g}}\right.$, & C & I will walk in integrity of heart \\
\hline & & & . yt ijB eb r $q \beta]$ & d & within my house. \\
\hline \multirow[t]{10}{*}{ II } & $\mathrm{B}$ & 4 & ynyl ed ghik]t w a Aal $i^{3}$ & $3 a$ & I will not set before my eyes \\
\hline & & & $T[Y B A r b D]$ & $\mathrm{b}$ & anything that is base. ${ }^{11}$ \\
\hline & & 5 & yt anf; $\mu$ yf $\dot{\sigma} \sec c\{\}$ & C & The doing of devious things ${ }^{12}$ I hate; \\
\hline & & & .YBiqBByial $i$ & $\mathrm{~d}$ & it shall not cling to me. \\
\hline & & 6 & 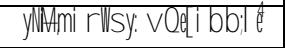 & $4 a$ & A perverted heart ${ }^{13}$ shall depart from me; \\
\hline & & & . I da eal il $r ;$ & $\mathrm{b}$ & wickedness I will not know. \\
\hline & $\mathrm{C}$ & 7 & 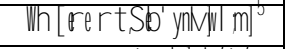 & $5 a$ & The one who secretly slanders ${ }^{14}$ his friend \\
\hline & & & t ymix gl $^{\prime} / \mathrm{t} / \mathrm{a}$ & $\mathrm{b}$ & I will put to an end; \\
\hline & & 8 & bot ebj I W W ynyl AHbGO & C & the one with haughty eyes and an arrogant heart \\
\hline & & & . $1 \mathrm{k}$ 消 a $\mathrm{i}$ it a 0 & $\mathrm{~d}$ & I will not tolerate. $^{15}$ \\
\hline \multirow[t]{8}{*}{ III } & $\mathrm{D}$ & 9 & Ar a Aynosata n $\mathbb{R}$ ]ynyl e & $6 a$ & My eyes will be on the faithful of the land \\
\hline & & & ydMlit byli & $\mathrm{b}$ & to let them dwell with me. \\
\hline & & 10 & 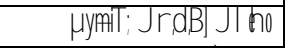 & C & He who walks in a blameless way, \\
\hline & & & . ynt e y yOalh & $\mathrm{d}$ & he shall serve me. \\
\hline & $\mathrm{E}$ & 11 & yt iB ebr a B Jbv ofla $i^{7}$ & $7 a$ & He shall not dwell in my house \\
\hline & & & hYmi jhc e 0 & $\mathrm{~b}$ & who practices deceit; \\
\hline & & 12 & 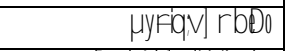 & C & He who speaks lies, \\
\hline & & & ynyl ed ghk] * K KyAa I 0 & $\mathrm{~d}$ & shall not be established before my eyes. \\
\hline \multirow[t]{4}{*}{ IV } & $\mathrm{F}$ & 13 & 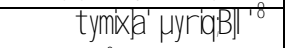 & $8 a$ & In the mornings I will destroy \\
\hline & & & Arantelli & $\mathrm{b}$ & all the wicked of the land, \\
\hline & & 14 & h wh yer y[ met yr khl] & $\mathrm{C}$ & to cut off from the city of Yahweh \\
\hline & & & 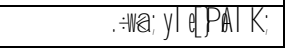 & $\mathrm{d}$ & all who do evil. \\
\hline
\end{tabular}


The psalm is characterised by the repetition of many words and ideas, forming inclusions, parallelisms and chiastic patterns. The divine name, Yahweh, occurs only in verse 1 and verse 8, thereby forming an inclusion of the psalm as a whole. Table 1 provides a list of words that are repeated in Psalm 101. Based on its poetic and stylistic features, six strophes (A-F) which form four stanzas (I-IV) can be identified. The structure can be summarised as follows:

\begin{tabular}{|c|c|c|c|}
\hline & A & I will live an upright life & \\
\hline & $\mathrm{B}$ & I will not accept these things & \multirow{2}{*}{$\begin{array}{l}\text { I will not accept this type of } \\
\text { conduct }\end{array}$} \\
\hline & C & I will not tolerate these persons & \\
\hline \multirow[t]{2}{*}{ III } & $\mathrm{D}$ & I will help these people & \multirow{2}{*}{ Who will dwell with me? } \\
\hline & $\mathrm{E}$ & I will not help these people & \\
\hline IV & $\mathrm{F}$ & I will remove these evil people from society & \\
\hline
\end{tabular}

The psalm contains some of the most detailed parallelisms and chiastic patterns found in biblical poetry. These features help to demarcate verse lines, but also higher-level units such as strophes and stanzas (Wendland 1998:101). The stanzas are demarcated with the help of themes that bind strophes together. Stanza II, for instance, is characterised by the use of the negative particle al, which is placed very prominently at the beginning of certain hemistichs. This stanza opens with al plus first person singular imperfect and ends in the same way. ${ }^{16}$ Stanza III is characterised by the use of the verb b v y, "to dwell".

There is an internal parallelism in verse line 1 (modifying phrase voluntative verb of singing // modifying phrase - voluntative verb of singing). There are also alliteration and rhyme between the two verbs that are so strategically placed at the end of the two hemistichs of verse line 1 . The word order is changed in verse line 2 , so that an external parallel is formed between verse lines 1 and 2, while the alliteration and rhyme found in line 1 is continued. The second hemistich of verse line 2 , however, does not seem to comply with this pattern. There is also an external parallelism between the first hemistichs of verse lines 2 and $3 .^{17} \mathrm{~A}$ verb in the imperfect first person, the preposition $b$, and the stem $\mu t$ are used to form the parallel. Because of the chiastic relationship between the first two verse lines, a weaker chiastic relationship is also formed between verse lines 1 and 3: There is a semantic parallel between "loyalty and justice", "a blameless way", and "integrity of heart", as there is also between "I will give heed" and "I will walk". In this way, the first strophe is bound together so strongly that it can also be demarcated as the first stanza. 


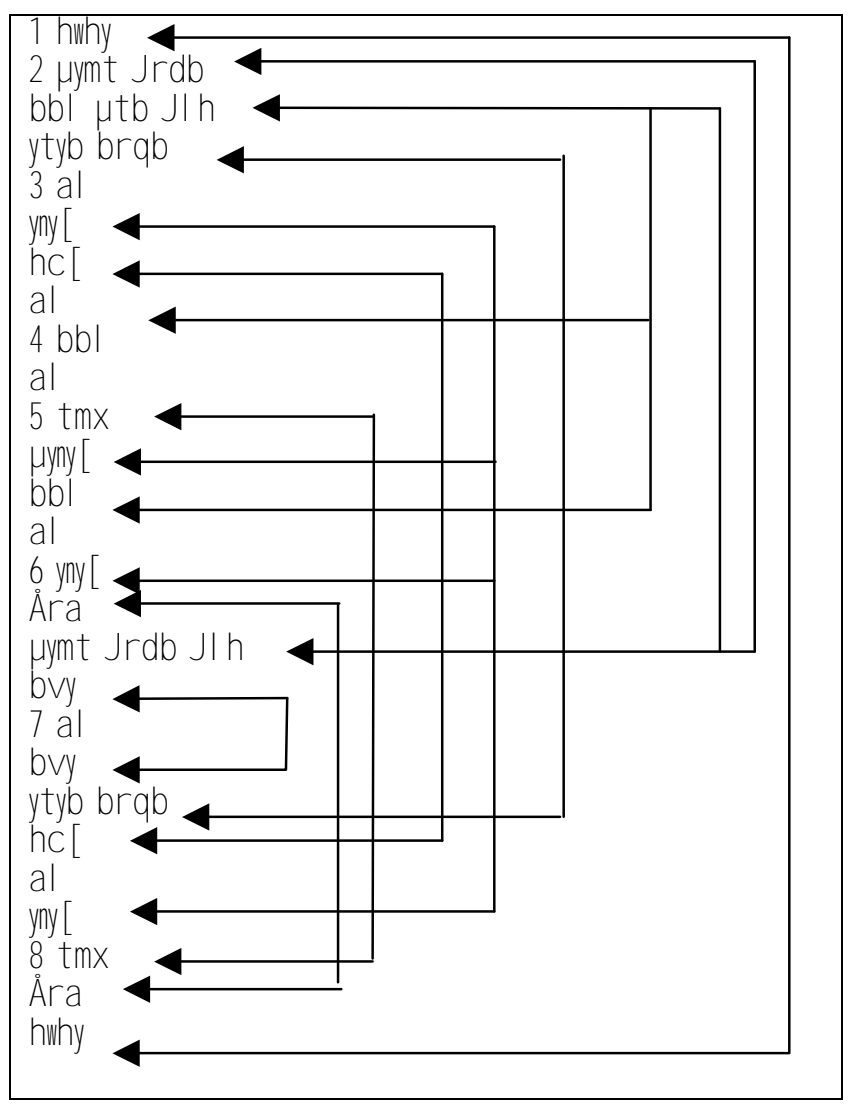

Table 1: The repetition of words and stems in Psalm 101

Although there has been efforts to find a symmetric arrangement of terms in Psalm 101, ${ }^{18}$ Table 1 shows that there is merely a general correspondence between the first half of the psalm and its second half. Watson (1986:284) has described the repetition of yt yb $b r q b$ ( $v v 2$ and 7 ) as an example of envelope figure. However, the repetition of lexical elements forms a network of links rather than a precise symmetry, unless certain words that are repeated, are ignored in the scheme.

All the verse lines of strophes $B$ and $C$ are related to a greater or lesser extent. While strophe A (= stanza I) contains four positive statements, strophes B and C (= stanza II) have four negative statements. ${ }^{19}$ Three of these combine al with a first person singular imperfect form. The three other statements in this stanza are positive pronouncements of dissociation ("I hate...", "it shall depart from me ...", "I will put to an end ..."). They are thus also parallel to the negative pronouncements on a semantic level. Verse lines 4 and 5 form a chiastic parallel: Verse line $4 i$ is an exact grammatical parallel of verse line $5 \mathrm{ii}$; verse line 4ii ("anything that is base") is a semantic parallel of "the doing of devious things" in verse line 5i. Both these phrases are also parallel in meaning to "a perverted heart" and "wickedness" in verse line 6. Verse lines 5 and 6 therefore also form a parallel (5i // 6i; 5ii // 6ii). Verse lines 7 and 8 also form parallels to verse lines 4,5 , and 6 , but they show greater 
similarity to one another to such an extent that they can be designated as a separate stanza. Instead of a general description of inequity, specific persons doing certain negative things or displaying wrong attitudes are mentioned: "the one who ...", "the one with ...." The second hemistich in each of these two lines also contains the nota accusativi and a first person singular imperfect form, although there is also a similarity between the negative particle with a verb in $4 \mathrm{i}, 5 \mathrm{ii}, 6 \mathrm{ii}$, and $8 \mathrm{ii}$.

As has been explained, the common denominator in the two strophes of stanza III is the use of the stem for "to dwell". Another feature of this stanza is the inclusio formed by "my eyes" in the beginning of verse line $9 \mathrm{i}$ and right at the end of verse line $12 \mathrm{ii}^{20}$ Such repetition is a well-known technique of demarcating units of text. In this regard, it is interesting to note the use of the words "not before my eyes" at the beginning of stanza II. Strophe D is demarcated within stanza III by the precise parallel between verse lines 9 and 10. The phrase "the faithful of the land" is parallel to "he who walks in a blameless way"; and "to dwell with me" is semantically parallel to "he shall serve me." Strophe E forms an antithesis to strophe D ("to let them dwell ..." and "he shall not dwell..."). Verse lines 11 and 12 form a chiastic parallel in which all the elements are involved: The negative particle + imperfect 3 masculine singular + preposition + noun + suffix 1 singular + participle masculine singular + noun describing deceit are parallel to a participle masculine singular + noun describing deceit + negative particle + imperfect 3 masculine singular + preposition + noun + suffix first person singular. The formula is A-B-C-D-E-F-G // F-G-A-B-C-D-E. The function of this instance of chiasmus has been described by Watson (1986:206) as "emphatic denial".

Although verse lines 13 and 14 are parallel in thought to verse line 12 ("he shall not be established" being more or less parallel to "I will destroy"), it seems necessary to designate them as a separate strophe and even a separate stanza. The reasons are the following: Verse lines 13 and 14 form a very close chiastic parallel. The verb t ymx a in verse line 13 has also occurred towards the end of stanza II and the noun Ar a in verse line 13 has also occurred in the beginning of stanza III. This, together with the three-fold incidence of hyperbole in verse lines 13 and 14 seem to indicate that the status of this close-knit unit is that of a summary conclusion to the poem as a whole. ${ }^{21}$ The instances of hyperbole are formed by the use of a plural form "in the mornings" and the use of the noun I k : "all the wicked", "all who do evil". The chiastic parallel between verse lines 13 and 14 has the formula A-B-C-DE // B-A-C-D-E. Element A represents the modifiers "In the mornings ..." and "from the city of Yahweh". The other elements should be easy to identify. 
Verse lines 13ii and 14ii also have parallels in sound, involving assonance as well as alliteration.

\section{TEXTUAL FUNCTION OF PSALM 101}

A number of conspicuous characteristics have emerged so far in the analysis. The author of this text had an excellent command of techniques such as parallelism, chiasmus, repetition, inclusion, antithesis, assonance, alliteration, and rhyme. These stylistic techniques were used to demarcate verse lines, strophes, and stanzas and to meld the different units into a whole. So many connecting lines criss-cross over the psalm, that the chance seems very remote that it had a complex history of development as some investigators would have us believe. Part of the strategy of the author was to let one person, someone with high authority, speak throughout the psalm. This authorial speaker uses words of dissociation from certain activities and words of association with certain other activities. By doing this, certain actions and attitudes are grouped together as undesirable and others as worthwhile and desirable:

\begin{tabular}{|l|l|}
\hline Words of association & Actions, attitudes, and persons \\
\hline I will sing of & Loyalty and justice \\
\hline I will sing to & You, Yahweh \\
\hline I will give heed to & A blameless way \\
\hline I will walk in & Integrity of heart \\
\hline My eyes will be on; to let them dwell with me & The faithful of the land \\
\hline He will serve me & Who walks in a blameless way \\
\hline Words of dissociation & Actions, attitudes, and persons \\
\hline I will not set before my eyes & Anything that is base \\
\hline I hate, it shall not cling to me & The doing of devious things \\
\hline It shall depart from me & A perverted heart \\
\hline I will not know & Wickedness \\
\hline I will put to an end & The one who secretly slanders his friend \\
\hline I will not tolerate & $\begin{array}{l}\text { The one with haughty eyes and an } \\
\text { arrogant heart }\end{array}$ \\
\hline He shall not dwell in my house & He who practices deceit \\
\hline He shall not be established before my eyes & He who speaks lies \\
\hline I will destroy in the mornings & All the wicked of the land \\
\hline (I will) cut off from the city of Yahweh & All who do evil \\
\hline
\end{tabular}

The effect of this categorising is that a kind of entrance liturgy to the palace or governor's house and presence is created, much the same as Psalm 15 and Psalm 24 constitute codes of conduct for entering into the temple. ${ }^{22}$ The communicative function of the psalm seems to be twofold. First, it signifies that the speaker subjects himself to a higher authority, acknowledging his own responsibility to avoid malpractices and promising to remain accountable. This must have been a great comfort to his subjects who certainly knew (or had first-hand experience of) the effects of tyranny. If such good qualities 
disappeared during the reign, any singing or reciting of the hymn would serve to emphasise the discrepancy between the ideal and reality, implicating the person in highest authority. On another level, the reciting or singing of the hymn would also have a chastening effect on society. The ruler or congregation quoted with this hymn the official opinion on what was considered to be actions, attitudes, and persons that were in accord with the ethos of the community and what not. In the view of the author or authors of the document, certain things were conducive to the well being of society, while others were detrimental. It should be very informative about the society in Ancient Israel to try to define these things.

\section{SOCIAL VALUES INCORPORATED IN THE STRATEGY OF PSALM 101}

One of the important concepts in this psalm is described by phrases such as uymt $|r d b| k c, b b|\mu t b| \mid h$, and $\mu y m t|r d b| \mid h$. Keeping the dangers of illegitimate totality transfer in mind, the following list of meanings can be gleaned from a dictionary: ${ }^{23} \mu$ Tocompleteness, integrity, fullness, innocence, simplicity, $b b \mid e \mu T \rho$ integrity of mind. $\mu T$; complete, perfect, sound, wholesome, morally innocent, having integrity. $\mu$ ymi ' complete, sound, whole, entire healthful, unimpaired, innocent, having integrity: of God's way; work; law; what is complete, entirely in accord with truth and fact. Koch (1976:1047) also says of the noun $\mu_{0} \mathrm{o}$ "in der Weisheit wird tōm zu einem thematischen Begriff und umreißt die "Vollständigkeit" eines bleibend gemeinschaftstreuen Menschen, dem nach Meinung der Sprüche die Gewähr eines künftigen heilvollen Ergehens entspringt."

These phrases obviously represent the concept of "wholeness" as it has been identified and described by social-scientific investigators of the Bible. ${ }^{24}$ According to Neyrey (1998:204), this is the fundamental value expressed in the creation story of Genesis 1 and in the premier commandment to love God with the whole heart, soul, mind, and strength. Wholeness is concerned with the integrity of human thought and action, so that true righteousness means a wholeness of belief and behaviour as it is described in the book of James in the New Testament (Neyrey 1998:205). Wholeness means that the human domains of action (expressed by the metaphors "hands" and "feet") ${ }^{25}$ and thought (represented symbolically by "eyes" and "heart") ${ }^{26}$ should be in accord. In this psalm, "integrity of heart" (v 2c) is contrasted with "a perverted (or "twisted" or "devious") heart" (v 4a) and "a blameless way" ( $v$ 6c) with the "practice of deceit" ( $v$ 7b). Some of the negative values mentioned in the psalm seem to form a semantic field that represents the opposite of wholeness and integrity. The shaded areas in the 
Psalm 101: Inaugural address or social code of conduct?

following list of positive and negative social values seem to form two opposing semantic fields:

\begin{tabular}{|l|l|}
\hline Positive social values & Negative social values \\
\hline Loyalty & A base thing \\
\hline Justice & The doing of devious things \\
\hline A blameless way & A perverted heart \\
\hline To walk in integrity of heart & Wickedness \\
\hline To be faithful & To secretly slander one's friend \\
\hline To walk in a blameless way & $\begin{array}{l}\text { To have haughty eyes and an arrogant } \\
\text { heart }\end{array}$ \\
\hline & To practice deceit \\
\hline & To speak lies \\
\hline & To be wicked \\
\hline & To do evil \\
\hline & \\
\hline
\end{tabular}

The "loyalty and justice" mentioned in verse $1 \mathrm{~b}$ seem to refer to qualities of Yahweh, ${ }^{27}$ since these terms are used in parallel to the person of Yahweh. They are sometimes used, however, to describe the required attitude of members of a group towards one another, for example in Hosea 12:7. ${ }^{28}$ What is more, there is a chiasmus formed between verse line 1 and verse line 2. This results in the words "loyalty and justice" forming a parallel not only to "Yahweh", but also to "a blameless way" which definitely concerns human action. The rest of the strophe and the whole psalm, in fact, focus primarily on human action. ${ }^{29}$ It does not seem far-fetched, therefore, to understand the "loyalty and justice" mentioned here as qualities of Yahweh that form the basis also for the conduct of the king towards his subjects and of the interaction of the people of Yahweh with one another. ${ }^{30}$ By juxtaposing verse lines 1 and 2, the "loyalty and justice" of Yahweh are defined as the fountainhead of the king's loyalty and justice and the ethical basis of interpersonal conduct within the in-group. It is included among the qualities that are required for the establishment of a viable social community. "Loyalty" or "steadfast love" often refer to the reliability of the support one can expect from one's family and from the relationships that replicate the family situation (Pilch 1998b:184). In this regard, the expression "the faithful of the land" may also refer to interpersonal reliability and integrity. Abraham, Moses and Samuel were all called tman (Neh 9:8; Num 12:7; and 1 Sam 2:35 respectively) with regard to their relationship with Yahweh. But the form is used sometimes simply to describe a reliable or trustworthy person. ${ }^{31}$ It thus seems acceptable to include the terms "loyalty and justice" and "faithfulness" under the heading of "wholeness and integrity." This refers in first instance to the perfect integrity of Yahweh, but forms the basis for interpersonal relationships as well. ${ }^{32}$ 
Among the negative values, there are two that involve actions (the "doing of devious things" and the "practice" of "deceit"); one that involves cognitive function ("a perverted heart"); and two that refer to insincere speech ("one who secretly slanders his friend" and "he who speaks lies"). All of these, however, can be described as actions that display a lack of integrity and therefore "wholeness." Some of the others can refer to any kind of transgression, not necessarily interpersonal deficiency ("a base thing", 33 "wickedness", "to be wicked", and "to do evil").

The phrase "haughty eyes and an arrogant heart" actually refer to the core values of honour and shame. It designates one who does not know or ignores on purpose the social status accorded to him by society or before God. As in the case of Psalm 131:1, it can refer to arrogance in the presence of Yahweh. Compare in this sense the attitude of "sinners" in Proverbs 21:4:

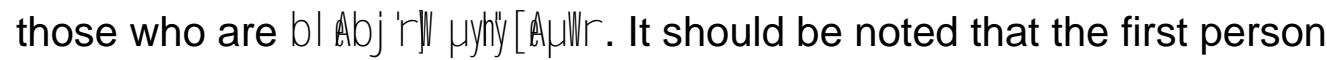
speaker acts with the authority of Yahweh himself. It is as the representative of Yahweh that this speaker condemns attitudes, inclinations, and secret sins such as slander, insincerity, arrogance, deceit, and lying. Haughty eyes and an arrogant heart are included among the things that will not be tolerated, because these are root causes of insincerity in the community. Therefore, it still holds true to say that actions and attitudes that are condemned in this psalm in general relate to the semantic field of "lack of integrity."

It is significant that space is used in this psalm as an instrument to define the process of dissociation of the speaker to those actions and attitudes that are undesirable. The inverse process of association and commendation similarly makes effective use of space: "the midst of my house" is the place where certain things will not be tolerated and others will be cultivated. The speaker himself will "walk in integrity within (his) house." He will not tolerate anything that is base "before (his) eyes." Devious things will not "cling" to him. A perverted heart will "depart from (him)." The faithful of the land "will dwell with (him)", those who walk in a blameless way "will serve (him)", but those who practice deceit or speak lies "shall not dwell in (his) house" or "be established before (his) eyes." Finally, all who do evil will be "cut off from the city of Yahweh." The city of Yahweh as a more general area, the house or palace of the speaker in greater detail, and the presence of the speaker $^{34}$ in particular function as areas that must be protected from the presence of people who do not deserve to be there or who simply do not belong there. This shows the importance of the social value of having margins and borders and of guarding purity. Purity was a characteristic of someone who knew how to be clean rather than unclean and therefore how to maintain honour and avoid shame (Pilch 1998b:170). The forms of insincerity 
mentioned in the psalm represent internal contradictions that had to be removed. The "wicked" and the "doers of evil" who are in the land and in the city of Yahweh possibly represent an external threat to the purity of the land and Jerusalem. For that reason the speaker announces the intention to destroy them and cut them off from the city of Yahweh. In doing so, he uses the means value of over-assertion to maintain and enhance the distinction between honour and shame (cf Pilch 1998a:50): people who were members of these groups would be destroyed "in the mornings". This assertion is best explained as an instance of hyperbole that aims at maintaining the honour of the in-group and shaming the out-group of evildoers. Strong rhetoric such as this is interpreted as the words of a powerful person. ${ }^{35}$

It seems that the speaker in this psalm is referring from beginning to end to the social value of patronage.$^{36}$ As a member of royalty or the elite of society, he has the power to provide help in the form of accommodation and security to certain clients. By setting out the personal and interpersonal qualities required before one could enter into such a relationship with him, he is effectively describing the ideal client. ${ }^{37}$ Such a client would be one who would prove to be trustworthy and reliable towards fellow citizens. ${ }^{38}$ One who slanders, deceives, and lies would not be acceptable, since such actions deprive the fellow members of the group of attaining an honourable existence. The reason why someone would indulge in such actions would be to increase one's own honour in disregard of that of others. That is perhaps why "haughty" and "arrogant" persons are also excluded.

Viewed from the perspective of social values in the world of the Bible, the function of this text is therefore to establish the boundaries of the "ingroup." It answers the question: "Who is suitable for service before the king, who are the persons who can be regarded as trustworthy and loyal to the people of Yahweh?" Through a process of differentiating between desirable and undesirable actions and attitudes, and linking these to the values of honour and shame, the speaker enhances his own honour and enforces his views of acceptable and unacceptable social practice. This serves to constitute an in-group, to define its ethos, and to enhance the abhorrence of the in-group to persons that do not comply with that ethos.

Verse $2 b$ ("When will you come to me") has not yet been discussed. With the exception of the heading, it is the only part of the psalm that has no parallel and does not seem to fit into the context. ${ }^{39}$ Kraus (1966:688) changes yt $\mathrm{m}$ into t ma $\hat{\mathrm{O}} \mathrm{His}$ translation reads "Truth will come before me." Loretz (1979:84) describes it as "Randglosse eines Lesers." Van der Ploeg (1974:169) leaves the text intact and suggests that this phrase must be understood in the light of Psalm 90:13 and especially Exodus 20:24 as the 
coming of Yahweh to bless a worshipper after the pledge of verse 2a has been made. Anderson interprets this as "a brief prayer by the King in the midst of his ritual humiliation" or as "a later addition" (Anderson 1981:701). Leupold (1977:701) ascribes the psalm to David and interprets this phrase as a longing to have the ark of the covenant with him in Jerusalem. Terrien (2003:694) suggests that this short prayer was the key to the preservation of the psalm, since it formed a "plaintive petition for God's intimate manifestation" in the Persian period when the psalm became a code of behaviour for a community in need of a monarch. He might well be correct in this description of the function of this phrase within the psalm in the post-exilic period. The psalm is an attempt to honour Yahweh ( $v 1$, the promises about integrity). As such, it is also an attempt to promote the honour of the in-group of the author. Vindication would come to them in the form of evidence that God is on the side of his people and their leader (cf Plevnik 1998b:108). In an original (inaugural) setting, it may have served simply to draw attention to the divine sanction of the authority of the speaker. The idea is created that there is a close association between speaker and Yahweh, although Yahweh"s presence is something that the speaker has to request, not a statement of fact.

\section{CONCLUSION}

Psalm 101 is evidently a text that is concerned with Israelite or Judaean society. ${ }^{40}$ It involves a person in power and refers to different members of a specific society that comprises the subjects of this king, prince, or governor. One part of this society exemplifies a certain ethos that is religiously founded in Yahwism and its codes of conduct. This group displays positive or commendable values such as a blameless life, integrity and faithfulness. Another section of society seems to ignore these values and prefers to pursue a life of doing devious things, wickedness, slander, arrogance, deceit, lies, and evil. By having the person in power speak words of association and dissociation, the author succeeds in strengthening certain values and the boundaries of the in-group. The speaker might have been a regent, prince, or king in the monarchic time, but at a later stage it could have been a religious functionary. While the in-group of faithful worshippers are encouraged and confirmed in their ethos, the outsiders are grouped together as a coherent unit of people who undermine the welfare of all and who should be exterminated. By using hyperbole, the speaker banishes them from the ideal society of the in-group, although in reality they probably continued to harass this society. ${ }^{41}$ The function of the text is therefore much more than simply a vow of a newly instituted sovereign. It also served a regulatory and group-identifying function 
from its inception onwards. It aimed at promoting the honour of the in-group by prescribing the abiding by certain social and religious values. It displayed a critical attitude towards certain types of (anti-social) behaviour and can therefore also be described as a persuasive text. It strategy is embedded in the authorial voice speaking, the use of specific semantic fields either with words of association or dissociation, repetition, and hyperbole.

In viewing Psalm 101 from a social-scientific perspective, one cannot help but to note the similarities in the intent and semantic fields of this psalm and Psalm $1 .{ }^{42}$ Both psalms are concerned with dissociation from certain groups of people and association with Yahweh and his people on the other hand. ${ }^{43}$ Prosperity and success (and thus honour) are promised to those who remain observant of the torah of Yahweh, while the wicked are threatened with dishonour, failure, exclusion and eventual extermination. While the book of Psalms begins in Psalm 1 with "a confident summons to obedience" (Brueggemann 1991:64), it ends in Psalm 150 with "the most extreme and unqualified statement of unfettered praise in the Old Testament" (Brueggemann 1991:67). Two-thirds through this composition, Psalm 101 can perhaps be regarded as a good example of a pledge to help with the establishment of an obedient and honourable society as envisaged in Psalm 1 so that the praise of Yahweh mentioned in Psalm 150 can be attained. This pledge is supposed to have the same sobering effect on society as the promises and threats of Psalm 1.

\section{End notes}

${ }^{1}$ Many exegetes after Gunkel have described the psalm as a royal psalm (Van der Ploeg 1974:167). According to some, it was used at the coronation of the new king (Gunkel 1929:433), according to others at a yearly commemoration of his ascent to the throne (e $\mathrm{g}$ Mowinckel 1962:66). Kraus (1966:689) describes it as "eine von der Intention des Bekenntnisses durchpulste Loyalitätserklärung ... in der ... ein König seine hqdx bezeugt." He regards it as belonging in a broad sense to the Gattung of "Königspsalmen", but more specifically as a "Loyalitätsgelübde des Königs" (Kraus 1966:689). According to Weiser (1975:648-649), the king does not give an account of the actual state of affairs, but "makes a declaration in which he expresses the lofty ideal principles whereby the conduct of a ruler shall be guided." He sees in the psalm also some form of influence from the Egyptian "Königsnovelle" (Weiser 1955:444). Seybold (1996:393) regards only the "Grundschicht und Vorlage" of the psalm (2aa, 3-5, 7) as a fragment of such a royal declaration. This politicalethical document was then incorporated into a prayer by (probably) a priestly official to express his religious political aim of ridding land and city from the wicked.

${ }^{2}$ Booij (1994:183) speaks of "iemand die een hoog ambt bekleedt." He points out that it is primarily the duty of the king to eradicate the wicked from the city of Yahweh. Prinsloo's (1988) attempt to prove that what is said in the psalm can be applicable to an ordinary citizen of Judah (cf the same idea in Loretz 1979:84), is not convincing. All the elements mentioned here together definitely point towards a ruler of some kind.

${ }^{3}$ The use of the prepositional phrase $b r a b$ with $t$ yb in verses 2 and 7 is conspicuous. In the Hebrew Bible, it is followed in the majority of cases by nouns referring to a group of people 
such as "Israel", "your people", "your enemies", "the nations", so that it can usually be translated with "among." One is therefore tempted to think that it refers to a dynasty in Psalm 101:2, but in the light of its repetition in verse 7, "palace" seems to be a more probable choice (so also Van der Ploeg 1974:169). The personnel of that palace and members of the royal family would then be the group of people "among" whom the speaker would practice integrity of heart.

${ }^{4}$ See also Weiser (1975:648) in this regard.

${ }^{5}$ The word is mostly used to describe service to God or the king (cf Van der Ploeg 1974:170).

${ }^{6}$ It would serve to express the intention of the king or regent to be loyal, to stay pure, and to exercise his right to judge conscientiously and justly (Kraus 1966:689).

${ }^{7}$ As Van der Ploeg (1974:168) remarks, "Zo is de psalm wel naar de vorm een soort regentenspiegel, maar hij is zo geschreven dat èlke vrome zich kan spiegelen aan de inhoud."

${ }^{8}$ Cf Elliott (1993:7): Social-scientific criticism studies the social aspects of the form and content of texts but also the conditioning factors and intended consequences of the communication process.

${ }^{9}$ The variant Mss and $y$ that read "I give heed to you in a blameless way" seem to contain the simplified and thus less probable reading.

${ }^{10}$ The reading found at Qumran, which uses the preposition I instead, does not make a real difference and can be explained as haplography.

${ }^{11}$ Or "anything wicked".

${ }^{12}$ It cannot be inferred without doubt that 0 had the plural participle ("doers of") in its Vorlage. The plural form $\mu$ yf $s$ seems to be a variant spelling of $\mu$ yf $c$, as the mlt Mss indicate. Brown, Driver \& Briggs (Whitaker 1997) have the following entry under $f$ c e f s e: "n.[m.] swerver, revolter (?), deeds that swerve (fr. the right?)." Koehler \& Baumgartner (1958:655) provide the Greek and Latin translation (parabasei $\sim$ praevaricationes) (transgressions), but describe the Hebrew word as "unknown." Davidson (1978:705) traces it to $f$ th and explains the form in the text as "one who turns aside". It is understood here as "devious" or "wrong" things. As a parallel to "a wicked thing" or "a base thing" in $\vee 3 b$, there can be no objection to read the infinitive (although t w $[$ is the more regular form) instead of the participle as many commentators have suggested.

${ }^{13}$ The expression is used in Proverbs 11:20 antithetically with $\mathrm{r} d \mathrm{~d}$ ymmt . The parallel with Psalm 101 is conspicuous.

${ }^{14}$ The text is written $(K)$ as yni $/ \mathrm{l} \mathrm{m}$ ( (a Po'al participle with suffix $1 \mathrm{~s}$ ) and read $(\mathrm{Q})$ as yni I $\left.\mathrm{m}\right](\mathrm{a}$ Pi'el participle with suffix) (cf Gesenius in Tregelles' translation, 1954:443). Leupold (1977:706) describes the $Q$ form as a sort of poel participle with an old case ending. According to him, it is in the construct state which is followed by a (prepositional) phrase. The verb is a derivative from "tongue" meaning "to slander." Koehler \& Baumgartner (1958) seem to be on the right track when they suggest that this should be read as $\mathrm{t}_{\mathrm{N}} \mathrm{Im} \mathrm{m}$, a Hiph'il participle without suffix with the meaning "he who slanders."

${ }^{15}$ The Septuagint's rendering of this with the phrase "with him I do not eat" seems to be a simplification of the more difficult Masoretic text. It is true, however, that the use of $I$ ky to

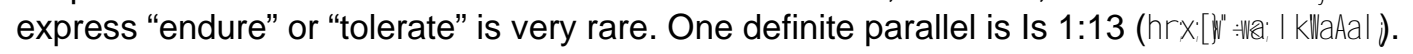

${ }^{16}$ So also Prinsloo (1988:119). 


\section{Psalm 101: Inaugural address or social code of conduct?}

${ }^{17}$ Watson (1986:182) describes this mistakenly (see the criticism of Loretz 1979:84) as an example of a chiastic tricolon. In this matter he seems to have followed Dahood (1970); cf Auffret (1982:307 n.7). See the discussion on $v 2 b$ later in this article.

${ }^{18} \mathrm{E} \mathrm{g}$, Auffret (1982). Based on the symmetry, he demarcates four units in the psalm: 1-2, 35,6 , and 7-8. This differs from the present segmentation in only one aspect, namely the separation of 6 and 7 and the consequent combination of 7 and 8 . The problem with finding such extensive symmetric patterns is the presupposition that the arrangement of words and letters is more important than the contents of what is said. If the symmetry can only be found through such a meticulous literary analysis, it would have remained hidden to those who used the text in ancient times and thus have communicated to very few people.

${ }^{19}$ This constitutes an antithesis between stanza I and stanza II.

${ }^{20}$ So also Prinsloo (1988:120).

${ }^{21}$ Terrien's endeavour (Terrien 2003:692-693) to separate $v 8 \mathrm{~cd}$ from the strophic structure as an "Envoi" (in which he has to insert a verb) is the result of his reliance on Mowinckel's idea that the "workers of iniquity" are magicians and sorcerers who deserve capital punishment (and thus a special bicolon). $\mathrm{V} 8 \mathrm{c}$ begins as a purpose clause that cannot be isolated from its antecedent sentence.

${ }^{22}$ Kraus (1966:691) thinks that the space around the king is the same space as that of the temple: "Die Sphäre, aus der er das Böse verbannt, ist identisch mit dem bereich des Heiligtums." This is so, according to him, because the Jerusalem sanctuary is a state sanctuary (Kraus 1966:689) and the king is responsible for guarding the entrance Torah (Kraus 1966:691).

${ }^{23}$ The dictionary of Brown, Driver \& Briggs, quoted from the electronic version, Whitaker 1997: in loco.

${ }^{24}$ Cf., for instance, Neyrey (1998:204-208).

${ }^{25}$ Cf Malina (1998b:98-102).

${ }^{26}$ Cf Malina (1998a: 68-72).

${ }^{27} \mathrm{Cf}$ the combination of these two qualities in Jer 9:23 (MT) as characteristic of the actions of Yahweh, although the usual word-pair is t mawds $j$. Kraus (1966:690) thinks that "ds j meint hier offensichtlich die der Davidsdynastie erzeigten Hulderweisungen Gottes." Seybold (1996:393394), on the other hand, regards these words as representing social values on which an orderly co-existence is based and for which Yahweh is thanked.

28 "Practice love and justice and live in confident dependence on your God." This command should be interpreted against the background of such texts as Hos 4:1, 6:6, and 10:12 which show that interpersonal loyalty was lacking. Leupold (1977:703) also refers to Is. 16:5 where "the same qualities are set forth as being distinctive of good human rule."

${ }^{29}$ Many exegetes simply state that the qualities are those of humans toward fellow humans. Cf e g Baethgen (1904:302) who goes so far as to say that these words cannot be characteristics of God in this context, since such things are not spoken of in the psalm. This seems to beg the question. Valeton (1913:156) considers them descriptions of the relationship of humans with Yahweh.

${ }^{30}$ In the words of Kraus (1966:692): "f p p mwds j sind Gaben und Aufgaben, de dem erwählten König aus Davids Geschlecht von Jahweh übertragen sind." Booij (1994:184) considers them to be not characteristics of Yahweh or the king in this instance, but independent entities, "al horen ze naar hun wezen bij de sfeer van YHWH." 
${ }^{31}$ E g Prov 11:13 "A gossip reveals secrets, but the faithful of spirit (=trustworthy) can keep a confidence."

${ }^{32}$ It should be kept in mind that morality in the world of the Bible is based on group values, not in abstract or "universal" principles (cf Moxnes 1996:27).

${ }^{33}$ De Liagre Böhl \& Gemser (1968:108) suggest that the second part of the Hebrew word | [ y l $b$ is related to the stem | [ $m$ which is used to express marital infidelity in Numbers 5:12, 19f, and 29. This would fit in with the semantic field identified here, but it is, unfortunately, doubtful.

${ }^{34}$ Kraus (1966:690) says the idea is created that the obedient king constitutes "eine Sphäre der Reinheit und Lauterkeit."

${ }^{35}$ As Pilch (1998a:51) explains: "The man who is eloquent and capable of strong rhetoric is viewed as a strong man." As Terrien (2003:693) and others before him have pointed out, there is a parallel here with Hammurabi who has also promised the removal of antisocial elements in the name of his god, Marduk. It is therefore not necessary to interpret these words as a priestly interpolation that represents a post-exilic (so Seybold 1996:395) or even Maccabean (so Briggs 1925:314) ideal.

36 "The patron-client relationship is a social, institutional arrangement by means of which economic, political, or religious institutional relationships are outfitted with an overarching quality of kinship or family feeling." (Malina 1998c:151).

37 The use of the verb "to hate" in v $3 c$ is significant, for it also points towards a patron-client relationship. Human treaty partners have relationships that are described with "love", "loyalty" (ds j ), and "hate" (cf Olyan 1996:210).

${ }^{38}$ People who live with the conviction that humans can do little to control nature, understandably search for security in the form of someone in whom they could place their allegiance in order to attain an honourable existence (cf Pilch1998d:201-202).

${ }^{39}$ Kselman (1985:46) has argued that there is a connection between $v 2 b$ and its context: "way" ( $v 2 a)$ relates to "come" (v 2b), while "to you" of v $1 c$ is related to "to me" of v 2b. From this he points to the fact that Psalm 101 concerns two participants in a dialogue (Yhwh and the king). They are both involved in $v 2 b$. Auffret (1982:306) has argued in a similar way for a connection between $v 2 \mathrm{~b}$ and $2 \mathrm{c}$.

${ }^{40}$ It could be pre-exilic, but the language and diction and resemblances to Proverbs point towards the post-exilic period (Van der Ploeg 1974:167). The use of enjambment and the object marker convinces Loretz (1979:84) that a pre-exilic dating can be excluded completely. According to Van der Ploeg (1974:170), the parallel formed between "the land" and "the city of Yahweh" in verse 8 points toward the post-exilic period. In this period, "the land" represented Jerusalem as the centre of Judaism. Baethgen (1904:302) and Kittel (1922:326) draw our attention to a remark of Theodoret about the psalm having had a heading in certain manuscripts of the LXX that read t et radi sabbatrou - "for the fourth day of the week." From this it seems clear that the psalm was used in Hellenistic times by the religious community in its Wednesday services. Baethgen (1904:302) interprets the expressions in vv 5, 6, and 8 as "dichterischer Personifikation der Gemeinde." Valeton (1913:157) similarly sees the psalm being spoken by the congregation as a declaration that everything is prepared for the coming of Yahweh as king. Kraus (1966:690), on the other hand, is confident with Gunkel ([1933] 1985:171) that it originated and was used in the monarchical period.

${ }^{41}$ Some of the transgressions mentioned in the psalm (e.g., v 5) can hardly be judged by a human being. The psalmist or speaker represents Yahweh's opinion in these matters. 
${ }^{42}$ Similarities between Ps 101 and Pss 5, 19, 24, and 34 have been noted by Van der Ploeg (1974:169). He also makes special mention of the dissociation in Ps 1:1 being parallel to the association expressed in Ps 101:6 (Van der Ploeg 1974:170).

${ }^{43}$ Psalm 1 speaks of not walking with the wicked or on the road of sinners; Psalm 101 speaks of giving heed to a blameless road and walking in integrity of heart. The things that are described as despicable in Psalm 101 would be the things warned against in the torah that Psalm 1 recommends as a guide for life.

\section{Works consulted}

Anderson, A A 1981. The Book of Psalms, Vol. II. Grand Rapids, MI: Eerdmans. $(\mathrm{NCBC}$.

Auffret, P 1982. Essai sur la structure littéraire du psaume 101, in Auffret, P, La sagesse a bâti sa maison: Etudes de structures littéraires dans l'Ancien Testament et spécialement dans les Psaumes, 301-319. Fribourg: Éditions Universitaires. (Orbis Biblicus et Orientalis 49.)

Baethgen, F. 1904. Die Psalmen, 2. Band, 3.Auflage. Göttingen: Vandenhoeck. (HK.) Booij, Th 1994. Psalmen deel III (81-110). Nijkerk: Callenbach. (De Prediking van het Oude Testament.)

Briggs, E G 1925. A critical and exegetical commentary on the Book of Psalms, Vol II. Edinburgh: T \& T Clark. (The International Critical Commentary.)

Brueggemann, W 1991. Bounded by obedience and praise: The Psalms as Canon. JSOT 50, 63-92.

Dahood, M 1970. Psalms III, 101-150: Introduction, translation and notes with an appendix, the grammar of the Psalter. New York: Doubleday.

Davidson, B 1978. The analytical Hebrew and Chaldee Lexicon. London: Samuel Bagster.

De Liagre Böhl, F M Th \& Gemser, B 1968. De Psalmen. Nijkerk: Callenbach. (Tekst en Uitleg.)

Elliott, J H 1993. What is social-scientific criticism? Minneapolis, MN: Fortress. (Guides to Biblical Scholarship.)

Gunkel, H [1929] 1986. Die Psalmen: Übersetzt und erklärt. 6.Auflage. Göttingen: Vandenhoeck \& Ruprecht.

Gunkel, H 1933 [1985]. Einleitung in die Psalmen: Die Gattungen der religiösen Lyrik Israels. Zu Ende geführt von J Begrich. Ergänzungsband zur II. Abteilung. 4. Auflage. Göttingen: Vandenhoeck \& Ruprecht.

Kittel, D R 1922. Die Psalmen, übersetzt und erklärt. 3. und 4. Auflage. Leipzig: Deichertsche. (Kommentar zum Alten Testament.)

Koch K 1976. Article s.v “ $\mu \mathrm{mt} t \mathrm{tmm}$ vollständig sein", in Jenni, E \& Westermann, C (Hrsg), Theologisches Handwörterbuch zum Alten Testament, Band II, 10451051. München: Chr. Kaiser Verlag.

Koehler, L \& Baumgartner, W 1958. Lexicon in Veteris Testamenti Libros. Wörterbuch zum Hebräischen Alten Testament in Deutscher und Englischer Sprache. Leiden: Brill.

Kselman J S 1985. Psalm 101: Royal confession and divine oracle. Journal for the Study of the Old Testament 33, 45-62.

Kraus, H-J 1966. Psalmen, 1. Teilband. 3., unveränderte Auflage. Neukirchen: Neukirchener. (BKAT.) 
Leupold, H C 1977 [1959]. Exposition of the Psalms. Herts: Evangelical Press.

Malina, B J 1998a. s v "Eyes-Heart", in Pilch \& Malina 1998:68-72.

Malina, B J 1998b. s v "Hands-Feet", in Pilch \& Malina 1998:98-102.

Malina, B J 1998c. s v "Patronage", in Pilch \& Malina 1998:151-155.

Mowinckel, S 1962. The Psalms in Israel's worship, Vol 1, tr by D R Ap-Thomas, Oxford: Blackwell.

Moxnes, H 1996. "Honor and shame" in Rohrbaugh, R L (ed), The social sciences and New Testament interpretation, 19-40. Peabody, MA: Hendrickson.

Neyrey, J H 1998. s v "Wholeness", in Pilch \& Malina 1998:204-208.

Olyan, S M 1996. Honor, shame, and covenant relations in Ancient Israel and its environment. JBL 115(2), 201-218.

Pilch, J J 1998a. s v "Dramatic Orientation", in Pilch \& Malina 1998:50-53.

Pilch, J J 1998b. s v "Purity", in Pilch \& Malina 1998:170-173.

Pilch, J J 1998c. s v "Steadfast Love", in Pilch \& Malina 1998:184-186.

Pilch, J J 1998d. s v "Trust (Personal and Group)", in Pilch \& Malina 1998:201-204.

Pilch, J J \& Malina, B J (eds) 1998. Handbook of Biblical social values. Peabody, MA: Hendrickson.

Plevnik, J 1998b. s v "Honor/Shame", in Pilch \& Malina 1998:106-115.

Prinsloo, W S 1988. Psalm 101: 'n Spieël vir konings en regeerders? in Prinsloo, W S \& Vosloo, W (reds), In mensetaal oor God se woord: Huldigingsbundel opgedra aan professor A $H$ van Zyl, 117-131. Kaapstad: Lux Verbi.

Seybold, K 1996. Die Psalmen. Tübingen: Mohr. (Handbuch zum Alten Testament I/15.)

Terrien, S 2003. The Psalms: Strophic structure and theological commentary. Grand Rapids, MA: Eerdmans. (The Eerdmans Critical Commentary.)

Valeton, J J P 1913. De Psalmen, Deel II: Psalm 73-150. $2^{\mathrm{e}}$ druk, herzien door Obbink, $\mathrm{H}$ Th. Nijmegen: $\mathrm{H}$ ten Hoet.

Van der Ploeg, J P M 1973. Psalmen, Deel II. Roermond: J J Romen. (BOT.)

Watson, W G E 1986. Classical Hebrew poetry: A guide to its techniques. Sheffield: JSOT Press. (JSOT Suppl Series 26.)

Weiser, A 1955. Die Psalmen, Zweiter Teil: Psalm 61-150. 4. neubearbeitete Auflage. Göttingen: Vandehoeck \& Ruprect. (Das Alte Testament Deutsch.)

Weiser, A. 1975. The Psalms: A commentary, tr by H Hartwell. London: SCM. (OTL.)

Wendland, E R 1998. Analyzing the Psalms: With exercises for Bible students and translators. Winona Lake, IN: Summer Institute of Linguistics.

Whitaker, R (ed), 1997. The Abridged Brown-Driver-Briggs Hebrew-English Lexicon of the Old Testament. Oak Harbor, WA: Logos Research Systems. 